Çolak, H., Kağnıcıoğlu, C. H. (2021). "How Ready Are We? Acceptance of Internet of Things (loT) Technologies by Consumers", Eskişehir Osmangazi Üniversitesi iiBF Dergisi, 16(2), 401 - 426.

Doi: $10.17153 / o g u i i b f .877372$

Başvuru: 09.02.2021 Kabul: 01.05.2021

Araştırma Makalesi/Research Article

\title{
How Ready Are We? Acceptance of Internet of Things (IoT) Technologies by Consumers ${ }^{1}$
}

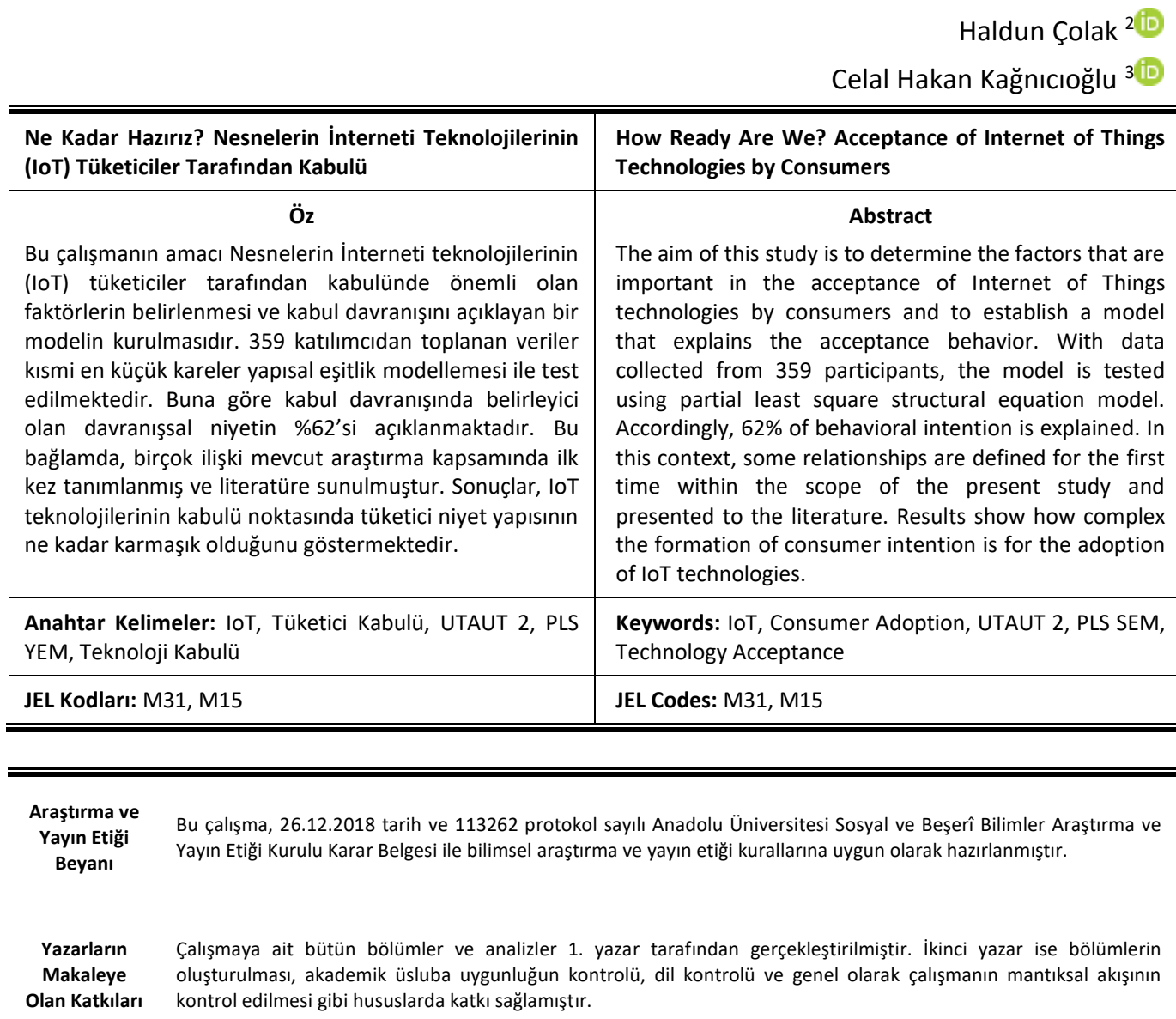

Çıkar Beyanı Yazarlar açısından ya da üçüncü taraflar açısından çalışmadan kaynaklı çıkar çatışması bulunmamaktadır.

${ }^{1}$ Bu çalışma Anadolu Üniversitesi Sosyal Bilimler Enstitüsü Pazarlama Anabilim Dalı́nda Prof. Dr. Celal Hakan KAĞNICIOĞLU danışmanlığında Haldun ÇOLAK tarafından "Nesnelerin İnterneti Teknolojilerinin Tüketiciler Tarafından Kabulüne İlişkin Bir Model Önerisi: Bir Uygulama” başlığı ile tamamlanarak 19.7.2019 tarihinde savunulan Yüksek Lisans tezinden türetilmiştir.

${ }^{2}$ Arş. Gör, Anadolu Üniversitesi, ỉktisadi ve İdari Bilimler Fakültesi, İşletme, halduncolak@anadolu.edu.tr

${ }^{3}$ Prof. Dr, Anadolu Üniversitesi, İktisadi ve İdari Bilimler Fakültesi, İşletme, chkagnic@anadolu.edu.tr 


\section{Introduction}

IoT technologies provide innovative and smart services and goods to users easing the life of consumers through smart devices. While loT technologies are commonly used in areas such as health, smart home automation, smart grids, military, automotive, transportation and logistics, and aviation, at the consumer level, it is in the early stages of usage (Kağnıcıoğlu and Çolak, 2019). However, with the potential of loT, the number of connected devices is expected to increase. For instance, according to reports, by 2025 , there will be an increase in the number of loT devices from 23 billion to 75 billion (Statista, 2016). This will cause a valuable market to emerge for companies and new areas to invest in for further market shares. With this in mind, IoT may influence consumer behavior in their daily lives with new approaches and opportunities they provide (Gao and Bai, 2014). Hence, the adoption and acceptance of loT technologies by consumers come across as an important research topic. Therefore, the present study aims to create a comprehensive model for the adoption of loT technologies by consumers and to examine whether the consumers are ready for these technologies.

Many theories and models such as Reasoned Behavior Theory (RBT), Planned Behavior Theory (PBT), Social Cognition Theory (SCT), Innovation Diffusion Theory (IDT), Technology Acceptance Model (TAM), and Unified Technology Acceptance and Use Theory 1 (UTAUT 1) have been developed to examine adoption behavior throughout the years (Kağnıcıoğlu and Çolak, 2019). With these theories and related models, researchers have investigated why users adopt technological products or systems or which factors play a critical role in this adoption behavior. As stated by Venkatesh et al. (2012), in addition to the models such as TAM 2 and UTAUT 1, more comprehensive and consumer-oriented models for the adoption of new technologies need to be developed. In this context, Venkatesh et al. (2012) created UTAUT 2 by adding three new variables: Hedonic Motivation (HM), Price Value (PV), and Habit $(\mathrm{HB})$ to the original variables, and Performance Expectations (PE), Effort Expectations (EE), Social Impact (SI) and Facilitating Conditions (FC) to adapt the original model to the consumer concept. Originally UTAUT 1 has been developed in an organizational context where the use of technology and adoption behavior may be mandatory as its primary starting point and the model is not suitable for the use and acceptance of consumer-oriented innovations such as smartwatches (Venkatesh et al. 2012). However, there is no organizational obligation for consumers and most consumers' behaviors towards technology are voluntary (Gaitán et al. 2015). Therefore, UTAUT 2 is presented by Venkatesh et al. (2012) to understand consumers' use of technology in general. In this respect, UTAUT 2 is considered to be the most comprehensive theory developed to explain consumer acceptance and use of new technologies (Gao et al. 2015). However, there are very few studies that directly use UTAUT 2 for the adoption of loT technologies (Gao et al. 2015; Brauner et al. 2017; Baudier et al. 2018; Beh et al. 2019). This also makes the current study among the first studies using UTAUT 2 in determining consumer adoption of loT technologies.

Recent studies show that security and privacy issues arising from the implementation of IoT are very important research subjects (Khattak et al. 2019; Tewari and Gupta, 2020; Ande et al. 2020). The main purpose of these studies is to show how the loT structure can be improved to provide better solutions against privacy and security issues. As stated by Martino

et al (2018), since the data exchanged within and among loT, frameworks are growing enduringly, there is the pervasiveness of such systems and that makes the control of the 
sensitive information rather difficult, ending up with security and privacy issues. The devices that can communicate with each other over the internet should be safe enough against external attacks. Otherwise, this can be a major obstacle to users' acceptance of loT technologies. That's why the authors consider security and privacy issues as important variable and put it in the model as a new variable.

Trust is another factor that could be effective for customers in the adoption of new technologies. A recent study shows that trust is a direct predictor of patients' behavior to accept technology in availing healthcare services (Dhaggara et al. 2020). According to Alhogail (2018), trust in the context of loT technologies is to rely on another asset that starts with the evaluation and expectations of consumers for the product or service to be used and to fulfill the expected or targeted purpose. When it comes to loT technology, trust can be expected to build on issues such as system usage security and user security. Since the consumer has to interact with devices that communicate with each other within the framework of the loT concept, situations such as uncertainty and vulnerability make trust very important for the consumer. Therefore, trust is an important variable that will affect consumers' intentions to use these products under all possible risks and in the context of an effort to overcome uncertainties (Yan et al. 2014).

Technology readiness index (TRI) can be interpreted as an integration of the beliefs and feelings of the individual towards technologies, which together determine the tendency of the person to adopt technological products or services. TRI has been extensively studied in many studies on the acceptance of new technologies or technological products and services. However, it can be said that this density is formed as an integrated study of TRI and TAM. In these studies, the indirect effects of THI sub-dimensions on behavioral intention were analyzed by examining the relationship between TRI sub-dimensions and TAM variables (Kuo et al. 2013; Roy and Moorthi, 2017). Besides its importance, to our knowledge, recent literature lacks having TRI sub-dimensions in explaining consumer adoption of loT technologies. In the current research, this gap is closed by adding TRI variables in the UTAUT 2 model and show the relationships with the other variables.

Within the context of the literature review, the present study has a significant contribution to the theoretical and practical aspects of the behavioral intention of consumers towards loT technologies. First, a new model is created and tested. In this respect, theoretically, some relationships that were not seen in the literature could be examined based on various theories in the model created within the scope of the present study. For example, while the relationship of optimism and innovativeness with performance expectancy, effort expectancy, and hedonic motivation variables have been examined in many studies (Ferreira et al. 2014; Roy and Moorthi, 2017; Rahman et al., 2017), the effect of optimism and innovativeness on habit and other variables were first discussed in the current study. In this context, the hypothetical model proposed in the context of the related literature is presented in Figure 1.1 to examine the mediation and indirect effects between behavioral intention and other variables for the future acceptance of loT technologies. 
Figure 1. Proposed acceptance model

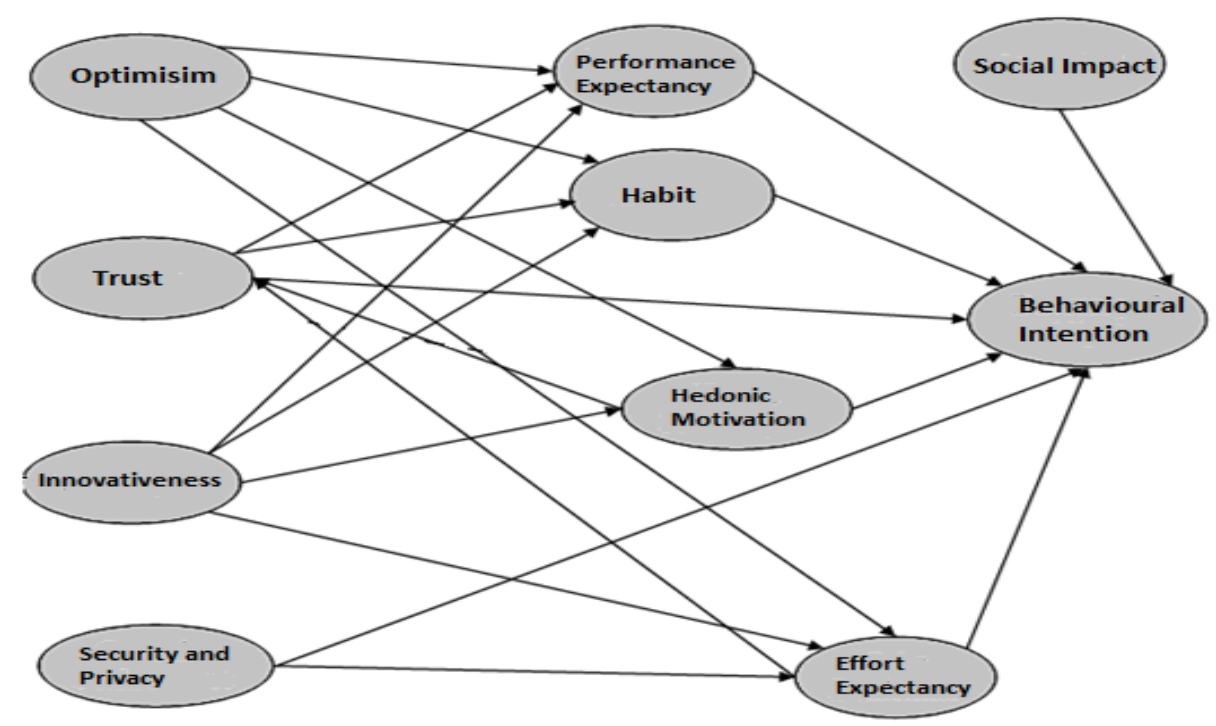

(Authors constituted the figure)

The remainder of this paper is structured as follows: Section 2 introduces the related literature and shows what the current study contributes. Section 3 shows the theoretical framework and describes the hypotheses. Section 4 gives the data, methodologies, and method used. Section 5 shows the findings. Results are discussed in section 6 with theoretical and practical implications. Section 6 also provides limitations and directions for future research.

\section{Theoretical background and hypotheses development}

\section{1. loT technology}

The concept of IoT has been gaining great interest in recent years due to the intensive usage of internet-related applications. IoT essentially is a large network of intelligent objects. As it is known, the classic Internet connects people together, while loT technologies enable objects to communicate independently with each other through integrated sensors (Hsu and Lin, 2016). Moreover, loT means that systems and connection frames in different communication patterns such as people to people, people to objects, and from object to object are mutually connected (Atzori et al. 2017).

Considering its general characteristics, the loT technologies also provide opportunities for companies to improve their market presentations, allowing for the creation of new market segments and the modification of existing solutions in areas such as production, logistics, and storage (Sułkowski and Spychalska, 2017). In the following years, this concept has developed in areas such as smart transportation, smart health care, smart homes, wearable smart devices, smartphones, etc. by covering a wide range of applications. Accordingly, the development and spread of IOT technologies day by day have brought along some infrastructural and data security problems. In parallel, today's studies generally investigate 
the technical, security, and various subsystem characteristics of loT technologies (Silva et al. 2018; Casola et al. 2019; Ande et al. 2020) to improve the general system. Some recent studies also focus on introducing new business models and new architectures for loT and devices to support the spread of it to new areas (Lee, 2019; Celic and Magjarevic, 2020).

Although it is important to carry out studies for the basic features of loT technologies and the solutions of some problems that come with them, as stated by Gao and Bai (2014), studies should also focus on examining the effects of consumer characteristics and social characteristics on the acceptance of consumer loT technologies. Therefore, this study aims to develop and test a model that identifies factors that are effective in relation to consumer acceptance of IoT technologies and explains acceptance behavior.

\subsection{Technology readiness index}

In general, the Technology Readiness Index (TRI) translates the individual's mental state related to technologies (Ferreira et al. 2014). TRI can be interpreted as an integration of the individual's beliefs and feelings towards technologies, which together determine the tendency of the individual to adopt technological products or services. Parasuraman and Colby (2015) grouped the tendency of people to be ready and adopt these technologies under 4 categories. Optimism and innovativeness have positive tendencies towards technology implying that new technologies contribute to the acceptance of new technologies, while discomfort and insecurity reflect negative tendencies implying that new technologies are obstructive to their acceptance of new technologies.

TRI has been extensively utilized in many studies aimed at the acceptance of new technologies or technological products and services. However, it may be stated that the focus of these studies is in the form of an integrated study of TRI and TAM. In these studies, the relationships between TRI sub-dimensions and TAM variables were examined and indirect effects of TRI sub-dimensions on behavioral intention were analyzed. Roy and Moorthi (2017), in their studies on the acceptance of mobile commerce applications, have found that TRI significantly affects perceived benefit and perceived ease of use and TRI plays an important role in the acceptance of mobile commerce applications in this aspect. Kuo et al. (2013) show that optimism has a significant effect on the expected perceived benefit for the adoption of medical registry systems. Finally, Zhang et al. (2017) found that there is a strong relationship between innovativeness and adoption intention of healthcare wearable technology.

As the literature review shows, we have limited knowledge about the fact that how TRI factors are effective in explaining the adoption behavior of consumers related to loT technologies. There is a big gap in this and this study also aims to show the relationship between TRI dimensions and UTAUT 2 variables to explain how complex the adoption behavior is.

\subsection{Consumer/User adoption studies in the era of loT}

As stated before, recent studies on the adoption behavior mostly focus on TAM or improving TAM by integrating different theories and variables to explain consumer adoption of loT technologies (Bölen, 2020; Park, 2020). These studies try to explain the adoption behavior in different contexts such as smart homes, smartwatches, and wearable devices and give new perspectives in such regard.

Some other studies try to create new models by integrating different theories and variables to explain adoption. However, the implication areas of these researches are not 
different from those use TAM or other acceptance models. Studies mainly focus on smartwatches (Nascimento et al. 2018 and Dutot et al. 2019), smart homes (Sanguinetti et al. 2018; Schill et al. 2019), and wearable devices (Zhang et.al, 2017; Kim and Park, 2019).

When it comes to IOT acceptance and UTAUT 2 integration, the literature appears to be in its infancy. Gao et al. (2015) investigate the factors associated with consumer's intention to adopt wearable technology in healthcare and they integrate UTAUT 2 with protection motivation theory and privacy calculus theory. According to results fitness device users are mostly affected by hedonic motivation, functional congruence, social influence, perceived privacy risk, and perceived vulnerability. Baudier et al. (2018) used UTAUT 2 as part of the smart home concept. While the security and health and comfort variables which are smart home dimensions affect performance expectation and habit, these two variables affect the intention to use. Brauner et al. (2017) examined the relationship between user characteristics such as age, gender and attitude, and intentions for smart textile products to be used in homes. Habit, Hedonic Motivation, and Performance Expectancy have become the leading descriptors on the intentions of consumers towards smart textile products with the model created based on UTAUT 2. Similarly, Beh et al. (2019) explain smartwatch adoption by using UTAUT 2 and perceived vulnerability and perceived severity as moderators. Findings show that performance expectancy, effort expectancy, facilitating conditions and hedonic motivation have positive impacts on behavioral intentions towards using smartwatches.

Finally, Kağnıcıoğlu and Çolak (2019) developed a model for consumer acceptance of IoT technologies. Here, a new model was established by adding trust, security, and privacy variables to UTAUT 2 variables. The main purpose of the study is to reveal whether the technology readiness index has a moderator effect on the acceptance of loT technologies. According to the research findings, the habit has a significant effect on behavioral intention. Also, interestingly, the effect of security and privacy on behavioral intention is fully mediated by hedonic motivation. In addition, it is stated that as consumers' level of technology readiness increase, more enjoyment, more perceived benefit and an easier use perception emerge.

When the research conducted by Kağnıcıoğlu and Çolak (2019) is taken as a reference, the present study has some similarities. In the present study, we used the same variables in the created model. However, differently, technology readiness sub-dimensions are included in the model to examine their indirect effects on behavioral intention. Also, we described new relationships between variables by making use of the literature. In these aspects, the present study tries to expand our knowledge related to loT technology adoption by consumers by discovering those new relationships. As we discuss later, the present study has new findings which enlighten us on how ready consumers are in terms of adopting new technologies.

\section{Hypotheses development}

In accordance with the literature, behavioral intention is considered the main determinant of consumer acceptance in this study (Venkatesh and Davis, 2000; Venkatesh et al., 2003). The main motivation here is that behavioral intention is the most important explanatory element of current use behavior. From a theoretical point of view, past studies reveal a strong relationship between users' beliefs and behavioral intention (El-Masri and Tarhini, 2017; Baudier et al. 2018). Therefore, theoretically, it may be stated that behavioral intention is considered as a single dependent variable in terms of explaining loT acceptance behavior 
(Gao and Bai, 2014). In addition, the study seeks answers to the following two research questions:

- How ready is the consumer at the point of adoption of loT technologies?

- Which factors determine the behavioral intention?

Social Impact (SI)

Social Impact is defined as the perception dimension of the beliefs of the people who are important for the individual and the necessity of using new technology (Venkatesh et al., 2003). At the core of social impact, as Thompson et al. (1994) express the people around us can associate us with the technologies we use and think that our behavior is influenced by our interaction with these technologies. In the current study, it is predicted that social impact will have a positive and significant effect on behavioral intention as has been shown by previous researches (Wu et al. 2016; Brauner et al. 2017, Lee and Shin, 2019).

H1: Social impact has a significant effect on the behavioral intention towards future adoption of loT technologies.

Performance Expectancy (PE), Habit (HB), and Trust (TR)

Firstly, performance expectancy was defined by Venkatesh et al. (2003) as the belief that the use of the system would improve the individual's work performance. However, in the consumer realm, Venkatesh et al. (2012) revised performance expectancy as the benefit of the use of technology by the consumer in performing certain activities. Performance expectancy has been described in the literature as a significant and effective factor in explaining behavioral intention in many studies (Hsu and Lin, 2016; Chipeva et al., 2018)

Limayem et al. (2007) define the habit as a tendency to perform behavior automatically based on past learning. Similarly, according to Kim et al., (2005), habit means automation and is related to past behaviors. Regarding consumer behavior, Venkatesh et al. (2012) emphasized that the habit factor was overlooked in previous studies and found that habit was an important explanatory element on behavioral intention in the UTAUT 2 model. In this context, it is revealed that habit is a critical factor in determining the consumer's intention to accept technology (Kim and Malhotra, 2005; Limayem et al. 2007; Brauner et al. 2017).

While trust is an important factor that affects consumer behavior and determines the success of the adoption of technologies, many definitions of trust have been made in the literature (Wei et al., 2009). However, according to Alhogail, (2018), trust in the context of loT technologies is the reliance on another entity for the fulfillment of the expected or intended purpose, starting with the evaluation and expectations of consumers for the product or service to be used. In the case of loT technology, trust can be expected to build on issues such as system use security and user security.

Trust also shapes the perceived benefit of the consumer towards technological products, and at this point, the consumer's belief in the capability and integrity of the target system can reflect the perceived benefit (Alalwan et al., 2018). Since trust covers the belief that technology or a system used has the elements that can perform the expected performance under different conditions, confidence reduces uncertainty about future behavior (Gefen et al. 2003) and this will increase the likelihood of the expected benefit for the consumer.

According to Limayem et al. (2007), habits tend to be performed automatically due to learning, while Kim and Malhotra (2005) suggest that habits are past behaviors. Regardless of 
whether they are conscious decisions or automatic behaviors, after a certain point, habits are influenced by trust (Kağnıcıoğlu and Çolak, 2019). According to Morrison and Firmstone (2000), when the consumer relies on an object for the execution of an action (such as use), trust becomes a habit on a recurring basis. Furthermore, Ajzen and Fishbein (2005) state that feedback from past experiences will shape many future beliefs or performances. Based on all of this, the future dependence of the consumer on loT technologies or their use becoming a habit for them will be shaped by the experiences and various learnings gained from the use of existing smart systems and the confidence that results from them.

H2: Trust has a significant effect on the behavioral intention for future adoption of loT technologies through habit.

H3: Trust has a significant impact on the behavioral intention for future adoption of IoT technologies through performance expectancy.

\section{Hedonic Motivation (HM) and Trust}

Hedonic motivation is defined as the pleasure and entertainment obtained after the use of technology and it is emphasized that it has an important role in explaining technology usage and acceptance behavior (Brown and Venkatesh, 2005). Many studies in the literature within the consumer dimension have investigated the effect of hedonic motivation on behavioral intention in the acceptance of intelligent products and systems (Ramantoko et al., 2016; Brauner et al. 2017).

With regard to the use of IoT technologies, the consumer's belief in entertainment and enjoyment will also affect the consumer's confidence in these technologies. According to Alalwan et al., (2015), since intrinsic motivation factors such as perceived entertainment affect the integrity and ability dimensions of trust, the trust of those who perceive the use of loT technologies as enjoyable, and entertaining will also increase. Consumers' pleasure as a result of the interaction with existing smart products and systems can affect the confidence that is developed for the future use of new technologies in this context.

$\mathrm{H} 4$ : Hedonic motivation has a significant effect on the behavioral intention of future adoption of loT technologies through trust.

\section{Effort Expectancy (EE) and Trust}

Effort expectancy is the degree of convenience of the consumer in relation to the use of technology (Venkatesh et al. 2012). AlHogail (2018) mentions that ease of use or usefulness will increase consumer confidence in relation to the availability of these systems and hence the interaction established. When IoT technologies fulfill the promised interaction environment and the practices that facilitate the daily life of the consumer, there will be no obstacles in the future for consumers to access and interact with these technologies.

$\mathrm{H} 5$ : Effort expectation has a significant effect on the behavioral intention for future adoption of loT technologies through trust.

Security and Privacy (SP)

Problems related to security and privacy are related to fears and worries such as illegal use of user information, infiltration of networks, financial loss, unauthorized use of personal information, etc. for new technology (Tsai et al., 2011). According to Shin (2010), security is the perception of the technology used to work properly and be guaranteed by the provider without risk. Therefore, the consumer's positive beliefs in the security and privacy issues 
associated with loT technologies will enable the consumer to gain a more optimistic view of the endeavor to use these technologies. The positive and significant effect of security and privacy on the behavioral intention at the point of adoption of new technologies has been demonstrated in many studies in the literature (Oliveira et al., 2016; Johnson et al., 2018; Aldossari and Sidorova, 2018). Although it is likely that consumers will adopt a timid approach when the data in question is of a sensitive nature, it is thought that security and privacy will have a positive impact on behavioral intention due to the experience of consumers' previous interactions with existing smart systems and the inherent ability of IoT technologies to facilitate daily life.

H6: Security and privacy have a significant impact on the behavioral intention for future adoption of loT technologies through effort expectancy.

\section{Technology Readiness Index Sub-dimensions and Other Variables}

The personality traits of consumers are important in terms of adopting new technology and making a purchase decision. According to Midgley and Dowling (1978), the innovation that shapes the consumer's adoption of new ideas, products, and technologies should be classified under personality traits. Innovativeness (INV) and optimism (OPT) not only help the consumer to adopt a particular product or service but also reduce the perceived risk associated with the use of that product or service (Manzano et al., 2009). Venkatesh et al. (2012) mention that the consumer's perception of innovation, optimism towards technology, and the desire to search for new things will regulate the effect of hedonic motivation on behavioral intention.

The automatic behavior of consumers who tend to be ready for technology will also affect their beliefs about becoming dependent on new technologies or gaining habits towards these technologies. Considering the characteristics of the consumers who are innovative and optimistic, it is foreseen that their repeated behaviors will be effective in the adoption of new technology (Limayem et al. 2007).

H7: Optimism has a significant effect on the behavioral intention of future adoption of loT technologies through performance expectancy.

H8: Optimism has a significant effect on behavioral intention towards future adoption of loT technologies through habit.

H9: Optimism has a significant effect on the behavioral intention for future adoption of loT technologies through hedonic motivation.

H10: Optimism has a significant impact on the behavioral intention of future adoption of loT technologies through effort expectancy.

H11: Innovativeness has a significant impact on the behavioral intention of future adoption of loT technologies through performance expectancy.

H12: Innovativeness has a significant impact on the behavioral intention of future adoption of loT technologies through habit.

H13: Innovativeness has a significant effect on the behavioral intention of future adoption of loT technologies through hedonic motivation.

H14: Innovativeness has a significant impact on the behavioral intention of future adoption of loT technologies through effort expectancy. 


\section{Methodology}

\section{Research model}

This research is a descriptive study aimed at revealing the relationships between optimism, trust, innovativeness, security and privacy, performance expectancy, habit, hedonic motivation, effort expectancy, and social impact and behavioral intentions of loT technologies for future acceptance (Figure 1.1).

\section{Sample}

The universe of the research is composed of consumers using any smart device. The sample group consisted of 359 university students attending the Faculty of Economics and Administrative Sciences in the 2018-2019 Academic Year Fall semester, studying in 5 different departments. 47.6 percent (171) of the students were male and 52.4 percent (188) were female. The average age of the students was found to be 22.5 with a standard deviation of 1.6.

\section{Data collection tools}

Questionnaires were used as data collection tools. The scale items were prepared as a 5point Likert scale referring to loT technologies ( $1=$ Strongly disagree, $5=$ Strongly agree $)$. UTAUT 2 scale items were adapted from Venkatesh et al. (2012), Trust items from Gefen et al. (2003), and Security and Privacy items from Chong and Chan, (2012). In addition, the technology readiness index scales, which reflect the intrinsic characteristics of consumers regarding technology, consisting of the sub-dimensions of innovation, optimism, insecurity, and discomfort, were adapted from Shin and Lee (2014).

\section{Data collection}

In this study, some demographic information such as gender, age, and study year/cycle were collected along with data on defined variables of loT technologies for future acceptance were collected. Before the data collection, the students have watched a video to introduce the concept of IoT. All data was then collected by the researcher in the classes. Ethics committee permission was obtained from the related institution before the study data was conducted.

\section{Data analysis}

Structural equation modeling with PLS consists of two stages: the evaluation of the measurement model and the evaluation of the structural model. Evaluation of the measurement model is mainly conducted by analyzing structure reliability, indicator reliability, convergent validity, and discriminant validity. Here, Cronbach's alpha and composite reliability values are examined for structure reliability. In addition, factor loadings are examined for item reliability and these loadings are expected to be above the threshold value of 0.7 , while items with reliability below 0.4 need to be eliminated (Churchill, 1979). Convergent validity is evaluated using AVE (Average Variance Extracted) and outer loadings (Hair et al., (2016).

One of the factors that should be examined for validity is discriminant validity, which means that one variable is different from other variables. Three criteria are considered when examining this validity: Cross loadings, Fornell - Larcker criterion, and Heterotrait-Monotrait (HTMT). However, as Henseler et al. (2016) state that HTMT creation gives more reliable results, we only used HTMT creation for discriminant validity. 
After examining the reliability and validity of the measurement model, the structural model should be evaluated. For the whole model evaluation, PLS SEM does not provide the general model fit values the way covariance based SEM does (Sevim et al. 2017). For the basic statistical analysis in the evaluation of the structural model; $R^{2}$, standard error, $\mathrm{p}$ value, $\mathrm{t}$ statistic value, $Q^{2}$ predictive power analysis and $f^{2}$ effect size analyses are used. In addition, as proposed by Tenenhaus et al., (2005) the GoF (Goodness of Fit) index, was also used in the evaluation. As a result of their evaluation, Wetzels et al. (2009) reported compliance values as the cut-off results of the analysis to be GoF $=0.1$ (low); GoF $=0.25$ (medium); GoF $=0.36$ (high).

\section{Results}

\section{Measurement model}

Construct validity was obtained with Cronbach's alpha values and composite reliability values. The threshold value of these two analyses are must be above 0.70 . Table 5.1 shows that Cronbach's alpha and composite reliability of the variables BI, EE, PE, SI, HM, HB, TR, SP, OPT, and INV are above the 0.70 threshold (Henseler and Sarstedt, 2013). The factor load of TR6 item shown in red in Table 5.1 is below the threshold value of 0.70 . However, as Hair et al. (2016) stated, the researcher should show restraint when discarding items in the value range of 0.6-0.7. These items should be kept in the model especially considering their theoretical importance in the research. Therefore, TR6 item was included in the evaluation. However, INV1 item (0.341) is excluded from the model. 
Eskişehir Osmangazi Üniversitesi İktisadi ve İdari Bilimler Fakültesi Dergisi

Table 1: Reliability and validity results of the measurement model

\begin{tabular}{|c|c|c|c|c|c|c|}
\hline \multirow{3}{*}{ Variables } & \multirow{3}{*}{ Items } & \multicolumn{3}{|c|}{ Convergent Validity } & \multicolumn{2}{|c|}{ Internal Consistency Reliability } \\
\hline & & Loadings & Indicator Reliability & AVE & $\begin{array}{l}\text { Composite } \\
\text { Reliability }\end{array}$ & Cronbach's Alpha \\
\hline & & $>0.7$ & $>0.5$ & $>0.5$ & $0.6-0.9$ & $0.6-0.9$ \\
\hline \multirow{4}{*}{ BI } & $\mathrm{BI} 1$ & 0.91 & 0.828 & \multirow{4}{*}{0.794} & \multirow{4}{*}{0.939} & \multirow{4}{*}{0.913} \\
\hline & $\mathrm{B} 12$ & 0.866 & 0.75 & & & \\
\hline & $\mathrm{BI3}$ & 0.922 & 0.85 & & & \\
\hline & $\mathrm{B} 14$ & 0.866 & 0.75 & & & \\
\hline \multirow{4}{*}{$\mathrm{EE}$} & EE1 & 0.847 & 0.717 & \multirow{4}{*}{0.711} & \multirow{4}{*}{0.908} & \multirow{4}{*}{0.863} \\
\hline & EE2 & 0.779 & 0.607 & & & \\
\hline & EE3 & 0.897 & 0.805 & & & \\
\hline & EE4 & 0.846 & 0.716 & & & \\
\hline \multirow{3}{*}{ SI } & SI1 & 0.808 & 0.652 & \multirow{3}{*}{0.75} & \multirow{3}{*}{0.899} & \multirow{3}{*}{0.837} \\
\hline & $\mathrm{SI} 2$ & 0.91 & 0.828 & & & \\
\hline & $\mathrm{SI3}$ & 0.896 & 0.803 & & & \\
\hline \multirow{3}{*}{ HM } & HM1 & 0.964 & 0.93 & \multirow{3}{*}{0.918} & \multirow{3}{*}{0.971} & \multirow{3}{*}{0.955} \\
\hline & HM2 & 0.967 & 0.935 & & & \\
\hline & HM3 & 0.943 & 0.89 & & & \\
\hline \multirow{4}{*}{ HB } & $\mathrm{HB} 1$ & 0.851 & 0.724 & \multirow{4}{*}{0.655} & \multirow{4}{*}{0.883} & \multirow{4}{*}{0.824} \\
\hline & HB2 & 0.74 & 0.548 & & & \\
\hline & HB3 & 0.777 & 0.604 & & & \\
\hline & HB4 & 0.862 & 0.743 & & & \\
\hline \multirow{4}{*}{ PE } & PE1 & 0.819 & 0.671 & \multirow{4}{*}{0.648} & & \\
\hline & PE2 & 0.812 & 0.66 & & 088 & 0821 \\
\hline & PE3 & 0.846 & 0.716 & & 0.88 & 0.821 \\
\hline & PE4 & 0.74 & 0.548 & & & \\
\hline & TR1 & 0.851 & 0.724 & & & \\
\hline & TR2 & 0.864 & 0.747 & & & \\
\hline TP & TR3 & 0.812 & 0.659 & 0626 & 0909 & 0901 \\
\hline IR & TR4 & 0.782 & 0.612 & 0.626 & 0.909 & 0.881 \\
\hline & TR5 & 0.737 & 0.543 & & & \\
\hline & TR6 & 0.688 & 0.473 & & & \\
\hline & SP1 & 0.902 & 0.814 & & & \\
\hline SP & SP2 & 0.931 & 0.867 & 0.835 & 0.938 & 0.902 \\
\hline & SP3 & 0.908 & 0.825 & & & \\
\hline & OPT1 & 0.876 & 0.767 & & & \\
\hline OPT & OPT2 & 0.89 & 0.792 & 0.699 & 0.874 & 0.785 \\
\hline & OPT3 & 0.744 & 0.554 & & & \\
\hline & INV2 & 0.778 & 0.605 & & & \\
\hline INV & INV3 & 0.832 & 0.692 & 0.546 & 0.815 & 0.713 \\
\hline & INV4 & 0.877 & 0.769 & & & \\
\hline
\end{tabular}

As mentioned before, validity is provided in two ways, as convergent and discriminant validity. Convergent validity is provided by the mean variance (AVE) described by Fornell and Larcker (1981). Bagozzi and Yi (1988) state that the structures in the model provide a high convergent validity if they are above 0.5 for AVE. AVE and the reliability results of all variables in the model are summarized in Table 1 . As can be seen, the reliability and AVE values of all variables are within the specified ranges or above the threshold values.

HTMT can measure discriminant validity with high sensitivity. With the HTMT, the extent to which the two corresponding variables are separated can be observed. All HTMT values 
should be below 0.85 . In our findings, there is a 0.83 relationship between TR and SP. Although it is below the threshold of 0.85 , a value of 0.83 indicates that these two structures may be close to each other. However, Henseler et al. (2016) emphasized that it is sufficient to have HTMT values below 0.9 for conceptually closely related variables. As a result, when HTMT criteria are examined, it is concluded that discriminant validity is provided in this study.

\section{Structural model}

The GoF value was calculated as 0.48 and indicates that a very good model fit value is achieved for the structural model. However, according to Henseler and Sarstedt (2013), the GoF value alone does not represent a true global cohesion value, and as suggested by Hair et al. (2016), it is necessary to analyze which variables $R^{2}$ values are formed, and $t$ values for the structural model.

Chin (1998) described values of $R^{2}$ ranges as 0.19 (weak); 0.33 (medium) and 0. 67 (high). In our findings, $R^{2}$ values for each dependent variable are HB (0.29); BI (0.62); TR (0.14); HM (0.25); PE (0.39) and EE (0.20) respectively. Accordingly, it is understood that the $R^{2}(0.62)$ value of the is quite high. Thus, $62 \%$ of the $\mathrm{BI}$ for future adoption of loT technologies can be explained by the variables PE, EE, HM, HB, SI, TR, SP, OPT, and INV.

In addition to the $R^{2}$ values, the $Q^{2}$ analysis, also known as the re-use technique of the estimator sample, can be used effectively for the estimation power evaluation of the model (Chin et al., 2008). This test is performed by running a procedure called blindfolding. As a result, $Q^{2}$ is automatically calculated for each dependent variable. The higher the $Q^{2}$ value above 0 , the greater the prediction power. $Q^{2}$ values of each dependent variables are $\mathrm{HB}$ (0.175), BI (0.459), TR (0.07), HM (0.215), PE (0.226) and EE (0.128). Findings show the predictive power of the model is at an acceptable level since $Q^{2}$ values are greater than 0 .

Multiple collinearity analysis is another type of analysis that is important in evaluating the structural model. Inner VIF values are for investigating the collinearity problem between a structure in the model and the other structures that are related. It is stated that the VIF value should be below 3.3 (Diamantopoulos and Siguaw, 2006) in some sources and less than 5 (Hair et al., 2016) in others. In the current study, VIF values are below both cut-off values. Therefore, it is understood that there is no multiple collinearity problem for the current model.

Peng and Lai (2012) emphasize that researchers should analyze the effect size of the predictive structures using Cohen's effect size coefficient $f^{2}$. The effect size $f^{2}$ is used to show the average relative variance increase in $R^{2}$. Cohen (1988) states that 0.35 (high); 0.15 (medium) and 0.02 (low) values are acceptable. Table 5.2 shows $f^{2}$ values for predictive variables. When the variables influencing the $R^{2}(0.62)$ of $\mathrm{BI}$ are examined, the variables with the greatest influence are $\mathrm{HB}(0.12)$ and $\mathrm{HM}(0.10)$. However, the effects of the SP $(0,01), \mathrm{PE}$ $(0.01)$ and $\mathrm{SI}(0.01)$ variables on the $R^{2}$ of $\mathrm{BI}$ seem to be beyond acceptable values. In other words, if these variables are removed from the model, the change in the $R^{2}$ of $\mathrm{BI}$ will be very small. 
Table 2: $\mathrm{f}^{2}$ values

\begin{tabular}{|c|c|c|c|c|c|c|c|c|c|c|}
\hline & $\mathrm{HB}$ & $\mathrm{BI}$ & $\mathrm{SP}$ & $\mathrm{TR}$ & $\mathrm{HM}$ & $\mathrm{PE}$ & $\mathrm{SI}$ & $\mathrm{INV}$ & $\mathrm{EE}$ & $\mathrm{OPT}$ \\
\hline $\mathrm{HB}$ & & 0.12 & & & & & & & & \\
\hline $\mathrm{BI}$ & & & & & & & & & & \\
\hline $\mathrm{SP}$ & & 0.01 & & & & & & & 0.02 & \\
\hline $\mathrm{TR}$ & 0.11 & 0.02 & & & & 0.16 & & & & \\
\hline $\mathrm{HM}$ & & 0.1 & & 0.04 & & & & & & \\
\hline $\mathrm{PE}$ & & 0.01 & & & & & & & & \\
\hline $\mathrm{SI}$ & & 0.01 & & & & & & & & \\
\hline $\mathrm{INV}$ & 0.03 & & & & 0.05 & 0.03 & & & 0.07 & \\
\hline $\mathrm{EE}$ & & 0.05 & & 0.04 & & & & & & \\
\hline $\mathrm{OPT}$ & 0.1 & & & & 0.16 & 0.18 & & & 0.06 & \\
\hline
\end{tabular}

The procedure recommended by Zhao et al. (2010) is followed to examine the mediation effects. To examine the mediation relationship, the significance of the total effect, direct effect, and indirect effects should be tested. The SmartPLS 3.2.8 package program calculates these three values and additionally provides "specific indirect effects" that show all other mediation relationships covering the entire model. From this perspective, it is expected that specific indirect effects, which also show other latent relationships in a whole model, will also be significant.

Direct effects show the significance of the different relationships within each of the 13 mediation hypotheses in total. When the path coefficients $(\beta)$ and $p$ statistical values of the mentioned relationships are examined, $\mathrm{HB} \rightarrow \mathrm{BI}(\beta=0.309 ; p<.001)$, SP $\rightarrow \mathrm{EE}(\beta=0.126 ; p<$ $.05)$, TR $\rightarrow$ HB $(\beta=0.293 ; p<.001)$, TR $\rightarrow \mathrm{BI}(\beta=0.145 ; p<.05)$, TR $\rightarrow P E(\beta=0.322 ; p<.001)$, $\mathrm{HM} \rightarrow \mathrm{BI}(\beta=0.270 ; p<.001), \mathrm{HM} \rightarrow \mathrm{TR}(\beta=0.217 ; p<.001), \mathrm{PE} \rightarrow \mathrm{BI}(\beta=0.108 ; p<.05)$, INV $\rightarrow$ HB $(\beta=0.155 ; p<.001)$, INV $>$ HM $(\beta=0.218 ; p<.001)$, INV $->P E(\beta=0.157 ; p<.001)$, INV $->$ $\mathrm{EE}(\beta=0.257 ; p<.001), \mathrm{EE} \rightarrow \mathrm{BI}(\beta=0.167 ; p<.001), \mathrm{EE} \rightarrow \mathrm{TR}(\beta=0.210 ; p<.001)$, OPT $->\mathrm{HB}$ $(\beta=0.298 ; p<.001)$, OPT $>$ HM $(\beta=0.373 ; p<.001)$, OPT $\rightarrow$ PE $(\beta=0.375 ; p<.001)$, OPT $->$ EE $(\beta=0.247 ; p<.001)$ appear to be supported. It should be noted that all the relationships given are defined in the mediation hypotheses. Among these relationships, only SP $\rightarrow \mathrm{BI}(\beta=-0.070$; $p=0.160)$ and $\mathrm{SI}->\mathrm{BI}(\beta=0.066 ; p=0.062)$ were not supported.

Before deciding whether mediation hypotheses are supported, the total and indirect effects, as mentioned earlier, should be examined. In this context, As the direct effects of SI -> $\mathrm{BI}$ and $\mathrm{SP} \rightarrow \mathrm{BI}$ relationships are not supported, $\mathrm{H} 1$ and $\mathrm{H} 14$ hypotheses should be rejected. However, since $\mathrm{H} 14$ is a mediation hypothesis, it will be retained in the model for further analysis. For other relationships that do not have problems in their direct effects, specific indirect effects and total effects should be examined. When the total effects are examined, there are no problems in the relationships of variables other than the SP and SI variables. However, when the specific indirect effects (including those not hypothesized) showing the mediation relationships of an entire model are examined, the paths of many mediation relationships are not supported. For example, although HM $\rightarrow$ TR $\rightarrow$ BI (H9) is significant, INV $>\mathrm{HM} \rightarrow \mathrm{TR} \rightarrow \mathrm{PE} \rightarrow \mathrm{BI}, \mathrm{HM} \rightarrow \mathrm{TR} \rightarrow \mathrm{PE} \rightarrow \mathrm{BI}, \mathrm{OPT} \rightarrow \mathrm{HM} \rightarrow \mathrm{TR} \rightarrow \mathrm{PE} \rightarrow \mathrm{BI}$ paths are not 
significant. The process to follow at this point is to determine which relationships break the mediating relationships within a whole model.

In the present study, since the aim is to create the model that best describes the $\mathrm{Bl}$, the model in which all relationship paths are significant will be shown. As a result of different variations carried out to this end, the model shown in Figure 1 was established.

Figure 2. loT technologies acceptance model (final model)

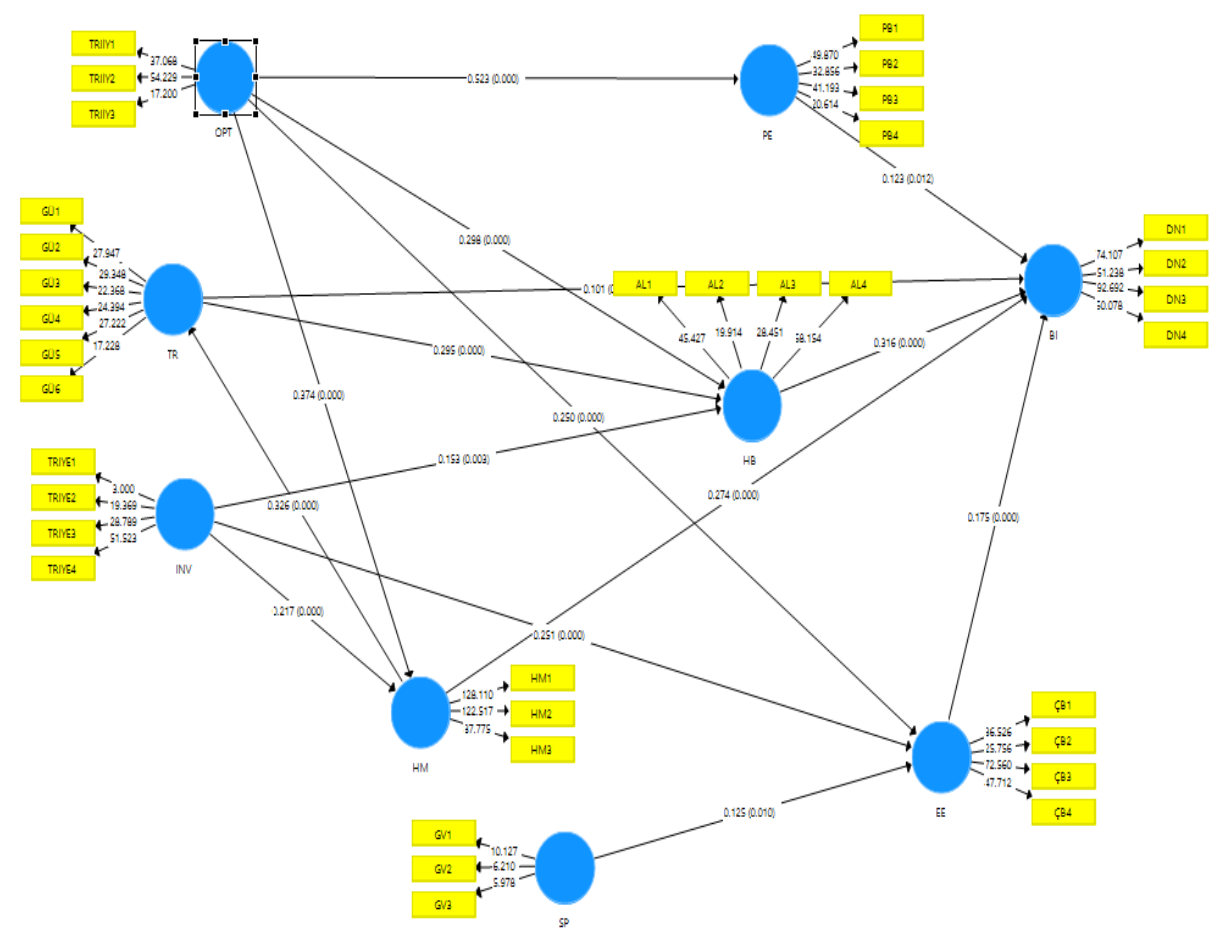

\section{Reliability and validity analysis of the final model}

According to the reliability and validity results of the final model, all reliability and validity values of the variables belonging to the new model are above the accepted threshold values. Only the factor load value of TR6 is below 0.708 at the limit. However, as stated by Hair et al. (2016), values in the range of 0.4-0.7 are also accepted in newly developed models and scales.

According to the HTMT results of the second model, it is understood that the average of the correlations of the items of all variables in the new model to the geometric mean of the correlations of the items of the variables in the corresponding row in the table is below the threshold value of 0.85 .

\section{The structural model investigation related to the final model}

Since there are no changes in the values of $R^{2}$ and $Q^{2}$ for the structural model, the values of the first model can be taken into account. Since there are small decreases in AVE values of only some variables, the GoF value decreased from 0.48 to 0.46 . Inner VIF values are also clarified. According to the findings, correlations between all variables do not cause a collinearity problem since the values are below the 3.3. or 5 thresholds. 
Table 3 shows significant changes when compared with Table 5.2, which shows $f^{2}$ values in the previous model. The values showing the $R^{2}$ effects of TR and PE in BI have increased from 0.01 for both variables to an acceptable limit of 0.02 . Thus, it can be concluded that the $\mathrm{SI}$ and SP variables removed from the model reduce the effects of TR and PE on BI. Other variables in the model explained $62 \%$ of the behavioral intention towards consumer acceptance of loT technologies in the future. Henseler et al., (2009) indicate that a value of 0.75 and above shows a very high and broad explanation power. In this context, considering the variables and the relationships established within the model, it explains behavioral intention at a very satisfactory rate.

Table 3. $\mathrm{f}^{2}$ values for the final model

\begin{tabular}{|c|c|c|c|c|c|c|c|c|c|}
\hline & $\mathrm{HB}$ & $\mathrm{BI}$ & SP & TR & $\mathrm{HM}$ & $\mathrm{PE}$ & INV & $\mathrm{EE}$ & OPT \\
\hline HB & & 0.13 & & & & & & & \\
\hline $\mathrm{BI}$ & & & & & & & & & \\
\hline SP & & & & & & & & 0.02 & \\
\hline TR & 0.11 & 0.02 & & & & & & & \\
\hline HM & & 0.1 & & 0.12 & & & & & \\
\hline $\mathrm{PE}$ & & 0.02 & & & & & & & \\
\hline INV & 0.03 & & & & 0.05 & & & 0.07 & \\
\hline $\mathrm{EE}$ & & 0.05 & & & & & & & \\
\hline OPT & 0.1 & & & & 0.16 & 0.38 & & 0.06 & \\
\hline
\end{tabular}

When the direct effects are examined (Table 4), it can be seen that all direct paths are significant. Within all relationships, it is understood that the variable with the greatest effect on $\mathrm{BI}$ is $\mathrm{HB}\left(\beta=0.316 ; \mathrm{p}=0.00^{* * *}\right)$.

Table 4. Path coefficients / direct effects related to the final model

\begin{tabular}{|c|c|c|c|c|c|}
\hline & Original Sample & Sample Mean & Standard deviation & T Statistics & P Values \\
\hline HB ->BI & 0.316 & 0.32 & 0.05 & 6.45 & 0.00 \\
\hline SP ->EE & 0.128 & 0.14 & 0.05 & 2.47 & 0.01 \\
\hline TR->HB & 0.296 & 0.3 & 0.05 & 6.3 & 0.00 \\
\hline TR ->BI & 0.101 & 0.1 & 0.04 & 2.49 & 0.01 \\
\hline HM->BI & 0.274 & 0.27 & 0.05 & 5.75 & 0.00 \\
\hline HM->TR & 0.326 & 0.33 & 0.05 & 6.66 & 0.00 \\
\hline PE -> BI & 0.123 & 0.12 & 0.05 & 2.49 & 0.01 \\
\hline INV -> HB & 0.155 & 0.16 & 0.05 & 3.11 & 0.00 \\
\hline INV > HM & 0.218 & 0.22 & 0.06 & 3.9 & 0.00 \\
\hline INV -> EE & 0.262 & 0.26 & 0.06 & 4.56 & 0.00 \\
\hline EE -> BI & 0.175 & 0.17 & 0.05 & 3.81 & 0.00 \\
\hline OPT ->HB & 0.296 & 0.3 & 0.06 & 5.28 & 0.00 \\
\hline OPT > HM & 0.373 & 0.37 & 0.06 & 6.6 & 0.00 \\
\hline OPT -> PE & 0.523 & 0.52 & 0.05 & 10.49 & 0.00 \\
\hline OPT -> EE & 0.245 & 0.24 & 0.06 & 4.2 & 0.00 \\
\hline
\end{tabular}

$* \mathrm{p}<.05, * * \mathrm{p}<.01, * * * \mathrm{p}<.001$

According to total effects results, which should be examined for the testing of hypotheses are examined, it is observed that all the paths are supported. In addition, relations previously not hypothesized; INV $\rightarrow$ HM $\rightarrow$ TR $\rightarrow$ HB $\left(\beta=0.021 ; p=0.003^{* *}\right)$, OPT $>$ HM $\rightarrow$ TR $\rightarrow$ HB $(\beta=$ $\left.0.036 ; p=0.001^{* *}\right)$, INV $>\mathrm{HM} \rightarrow \mathrm{TR} \rightarrow \mathrm{HB} \rightarrow \mathrm{BI}\left(\beta=0.07 ; \mathrm{p}=0.01^{*}\right), \mathrm{HM} \rightarrow \mathrm{TR} \rightarrow \mathrm{HB} \rightarrow \mathrm{BI}(\beta$ $=0.03 ; p=0.002 * *)$, OPT $\rightarrow$ HM $\rightarrow$ TR $\rightarrow$ HB $\rightarrow$ BI $\left(\beta=0.011 ; p=0.005^{* *}\right)$, INV $\rightarrow$ HM $\rightarrow$ TR $\rightarrow$ $\mathrm{BI}\left(\beta=0.07 ; p=0.044^{*}\right)$, OPT $>$ HM $\rightarrow$ TR $\rightarrow \mathrm{BI}\left(\beta=0.012 ; p=0.03^{* *}\right)$, INV $\rightarrow$ HM $\rightarrow$ TR $(\beta=$ $\left.0.071 ; p=0.001^{* *}\right)$ and OPT $->$ HM $->$ TR $\left(\beta=0.122 ; p=0.000^{* * *}\right)$ were discovered during 
the analysis in accordance with the nature of SEM. Here, the relations between OPT, INV, HM, $\mathrm{TR}, \mathrm{HB}$ and $\mathrm{BI}$ draw attention. In particular, it is seen that the effect of $\mathrm{HB}$ on $\mathrm{BI}$ is complex within the study. Therefore, based on all these relationship networks, which the general literature has not examined before, these appear to be unique findings discovered in the present study.

Finally, Table 5 shows the specific indirect effects of the final model. As can be seen from the table, all the mediation relationships in the model are significant. Thus, the hypotheses $\mathrm{H} 3, \mathrm{H} 4, \mathrm{H} 5, \mathrm{H} 6, \mathrm{H} 7, \mathrm{H} 9, \mathrm{H} 11, \mathrm{H} 12, \mathrm{H} 13$, and $\mathrm{H} 14$ are supported.

Table 5. Specific indirect effects of the final model

\begin{tabular}{|c|c|c|c|c|c|}
\hline & Original Sample & Sample Mean & Standard deviation & T Statistics & P Values \\
\hline INV $->$ HM $->$ TR $->$ HB & 0.021 & 0.021 & 0.007 & 2.928 & 0.003 \\
\hline HM $->$ TR $->$ HB & 0.097 & 0.101 & 0.025 & 3.827 & 0.000 \\
\hline OPT $->$ HM -> TR ->HB & 0.036 & 0.038 & 0.011 & 3.208 & 0.001 \\
\hline INV $->$ HM $->$ TR $->$ HB $->B$ I & 0.007 & 0.007 & 0.003 & 2.565 & 0.010 \\
\hline TR $->\mathrm{HB}->\mathrm{BI}$ & 0.093 & 0.095 & 0.021 & 4.393 & 0.000 \\
\hline HM $->$ TR-> HB $->$ BI & 0.030 & 0.032 & 0.010 & 3.160 & 0.002 \\
\hline OPT $->\mathrm{HM}->\mathrm{TR}->\mathrm{HB}->\mathrm{BI}$ & 0.011 & 0.012 & 0.004 & 2.828 & 0.005 \\
\hline INV $->\mathrm{HB}->\mathrm{BI}$ & 0.049 & 0.049 & 0.017 & 2.837 & 0.005 \\
\hline OPT -> HB $->\mathrm{BI}$ & 0.094 & 0.094 & 0.022 & 4.158 & 0.000 \\
\hline INV $->\mathrm{HM}->$ TR $->\mathrm{BI}$ & 0.007 & 0.007 & 0.004 & 2.014 & 0.044 \\
\hline HM $->$ TR $->$ BI & 0.033 & 0.034 & 0.014 & 2.375 & 0.018 \\
\hline OPT $->$ HM $->$ TR $->$ BI & 0.012 & 0.013 & 0.006 & 2.170 & 0.030 \\
\hline INV $->\mathrm{HM}->\mathrm{BI}$ & 0.060 & 0.059 & 0.019 & 3.186 & 0.001 \\
\hline OPT -> HM -> BI & 0.102 & 0.102 & 0.024 & 4.188 & 0.000 \\
\hline OPT $->$ PE $->$ BI & 0.064 & 0.064 & 0.027 & 2.367 & 0.018 \\
\hline SP -> EE -> BI & 0.022 & 0.023 & 0.010 & 2.141 & 0.032 \\
\hline INV -> EE -> BI & 0.046 & 0.045 & 0.016 & 2.923 & 0.004 \\
\hline OPT -> EE -> BI & 0.043 & 0.042 & 0.015 & 2.813 & 0.005 \\
\hline INV $->$ HM $->$ TR & 0.071 & 0.071 & 0.021 & 3.469 & 0.001 \\
\hline OPT-> HM -> TR & 0.122 & 0.125 & 0.029 & 4.198 & 0.000 \\
\hline
\end{tabular}

$* \mathrm{p}<.05, * * \mathrm{p}<.01, * * * \mathrm{p}<.001$

\section{Discussion}

This study examined the factors that affect the behavioral intention of consumers to adopt loT technologies in the future and the most comprehensive model to explain whether the consumer is ready for these new technologies. In the study, Unified Technology Acceptance and Use Theory 2 (UTAUT) 2 is accepted as the most advanced acceptance theory in the consumer realm. The variables of trust, security, and privacy, which are considered to be important factors in the adoption of loT technologies, have been added to the variables of the model developed (Kağnıcıoğlu and Çolak, 2019). Besides, innovativeness and optimism are included in the model with the expectation that they will shape many relationships within the structural model.

In the model, the direct effects of habit, performance expectancy, effort expectancy, hedonic motivation, social impact, trust and security, and privacy variables on behavioral intention and their relationship with optimism and innovativeness were examined. In this context, some relationships are defined for the first time within the scope of the present study and presented to the literature. In this respect, the results of the research stand out with their exploratory features as well as the original structure of the study. As a result of the 
relations established with the structural equation modeling method, many conclusions have been reached and this shows how complex the formation of consumer intention is at the point of adoption of technologies.

\subsection{Theoretical implications}

The belief that consumers will gain habits in loT technologies affects their behavioral intentions towards their acceptance of these technologies. As stated before, Habit is a learning process shaped by past experiences. This shows us that, as a result of their current experiences, consumers have become familiar with the use of smart technologies they currently use. In this context, consumers show that they believe that the unique opportunities that loT technologies will offer will be indispensable in their lives or part of their daily lives in the future. Habit is the most important factor explaining the consumer adoption of IoT technologies, and this result is compatible with Nascimento et al. (2018)' findings.

This study shows that consumers place trust in loT technologies. In addition, consumers believe that they can become more dependent on loT technologies, increasing the effect of trust on consumers' behavioral intentions (Kağnıcıoğlu and Çolak, 2019). As Limayem et al. (2007) state, habit is automatic learning that develops as a result of past experiences, therefore it is understood that there is trust in the experience that the consumer develops. Ajzen and Fishbein (2005) emphasize that many future beliefs can be shaped as a result of feedback from past experiences. Therefore, in parallel with what Morrison and Firmstone (2000) stated, it is concluded that trust can turn into a habit as a result of actual actions.

Users are convinced that this process will be fun for them, rather than considering the effort they will exert when using loT technologies. While loT technologies aim to make people's daily lives more comfortable, they will also create new communication environments and various entertainment patterns that will enable the consumer to enjoy using these technologies. Another important result is that hedonic motivation affects behavioral intention through trust. As consumers' confidence in loT technologies increases, the pleasure of using these technologies will increase and so will the behavioral intention for the adoption of these technologies in the future. As Luhmann (2000) states, behind all this, it can be said that the improved degree of familiarity will affect the consumer. Accordingly, as the degree of familiarity of a person or event increases, the degree of uncertainty in the person decreases, and the person feels confident about what he/she encounters. Therefore, consumers believe they acquire pleasure as a result of their interaction with existing smart technologies and systems and therefore they will seek similar pleasure and entertainment outputs after the use of loT technologies.

Security and privacy issues did not have a significant effect on behavioral intention in this study. The most important reason for this is that the consumer's experience with existing smart technologies and systems is insufficient to create familiarity with the security and privacy issues that will arise with the use of loT technologies. This is because as Venkatesh et al. (2012) stated when some familiar conceptual keys are observed in the future, one can establish an automatic or direct relationship between the past response and these conceptual keys. Interestingly, however, consumers' perspectives on security and privacy influence behavioral intention through their efforts to use these technologies. In fact, the consumer's belief that they can use these technologies without any effort reflects their belief that they have control over these technologies which increases their positive perceptions regarding 
security and privacy. The new relationship defined in the light of all these is presented as a unique and new output to the literature.

Optimism and innovativeness have a positive and significant effect on behavioral intention indirectly through performance expectation, hedonic motivation, and effort expectation. These findings concur with the results of many studies conducted in the literature (Kuo et al. 2013; Seol et al. 2017; Alalwan et al., 2018). In this study, the effect of innovativeness and optimism on behavioral intention through habit, which has not been examined in the literature before, is also revealed. According to the findings, the fact that consumers are innovative and optimistic increases their beliefs that they will gain habits in relation to the use of loT technologies, which also increases their behavioral intentions.

The lack of a significant effect of social impact on behavioral intention can be explained by the fact that consumers are innovative and optimistic towards technologies. People with high innovativeness and optimism will have high confidence in the use of new technologies. Innovative individuals, in particular, are the first to adopt these technologies by following the latest technological developments closely and assuming roles such as pioneers and opinion leaders. Therefore, as these people have different ways of accessing information, and since they are opinion leaders, they are not influenced by the opinions of others.

This study also shows the relationship networks that have not been examined before within the scope of many original and literature reviews. For example, because trust is the belief that non-abandonment by new technologies or the investment made for the benefit of the consumer (Gefen et al. 2003), the consumer feels more control over the use of the product, which increases the consumer's belief in greater pleasure and enjoyment. In addition, this relationship affects consumers' belief that they can depend on loT technologies. Based on the findings of the research, it can be said that the behavioral intentions of consumers towards the adoption of loT technologies are affected by variables such as hedonic motivation, trust, and habit rather than total benefit. Consumers are ready to use these technologies and tend to use them for a long time. In addition, as the optimism and innovativeness levels of consumers increase, so does their belief that they will achieve pleasure and entertainment through the use of loT technologies. This also affects the consumer's belief that they may become dependent on loT technologies while increasing their confidence in loT technologies. In terms of direct effects, the habit was found to be the variable with the greatest impact on behavioral intention. Therefore, it can be said that the relationship between optimism, innovation, hedonic motivation, and trust is effective in this influence of habit.

\subsection{Practical implications}

The most important implication for practitioners is the certainty that a broad cognitive and environmental process is involved in determining behavioral intention for future adoption of loT technologies. Especially when it comes to technological products, it is seen that consumer expectations for pleasure and entertainment surpass many variables. Practitioners are therefore required to design in a way that allows the consumer to have a pleasant time at when using loT technologies.

Practitioners should also pay attention to the fact that future potential users of future technologies tend to be ready for the technology. It can be said that as the tendency to be ready for technology increases in the consumer, they are more inquisitive and have access to 
information with their own resources and in this context, they tend to be opinion leaders. Therefore, the priorities of the users with a high level of technology readiness are not exactly total benefits, but rather as indicated by the results obtained in this study where they focus on topics such as fun content and trust. Presently, it is important for the companies producing smart products to take into account the pleasure and trust aspects sought by the consumer in their activities such as investment and design in loT technologies.

Considering that habit is an automatic learning process that occurs as a result of past experiences, some usage patterns that are used by the consumer should not be excluded in terms of the general functioning of the products. Although Ajzen (2002) states that the relatively unchanged content of the behavior can continue automatically in a wide range of ways, it should be noted that rapid change is a defining feature of the technology market when it comes to technology and consumers. Therefore, in a world of technology that surrounds the consumer with changes rather than a fixed technological environment, the emphasis can be placed on the development of designs and applications by accepting the existence of a consumer structure accustomed to rapid changes.

loT technologies should be able to offer features that fulfill the promised ease of use to the consumer in the future. The consumer believes they are in control through their knowledge and relatively positive experiences and think that the use of loT technologies will not be a problem for them at this point. Users believe that they will get more pleasure with the use of loT technologies as a result of this sense of control and this increases their belief that they can habitualize the use of these technologies. In this relationship where trust is a mediator, it is important to develop designs and applications that will not break consumers' confidence and trust in the ease of use of these technologies.

It is understood that security and privacy issues constitute an obstacle to the adoption of loT technologies. In this context, data security should be central to loT technologies. Companies need to be clear to the consumer about data security, privacy, and data usage policies. It should be noted that security and privacy issues will play an important role in consumer purchasing decisions and maintaining a user base.

\subsection{Limitations and future research directions}

The sample of the study is limited to the students of the Faculty of Economics and Administrative Sciences who are in the 3rd semester and above. Due to the high homogeneity of the sample, the results cannot be interpreted based on different income groups and ages. Facilitating conditions and price value which are two of the UTAUT 2 variables have not been used in this study because of the lack of existing infrastructure of loT technology, which is presented to consumers in a very limited framework of this technology and therefore, it is not possible to adapt the scale items of these two variables to the consumer. Also, discomfort and insecurity variables which are two of the Technology Readiness Index sub-dimensions were not included in the study due to the lack of correlations with other variables in the model. Although young people are considered to be the most important adopters of loT technologies in the future, inferences cannot be made regarding whether the results will change in other age groups.

One of the results that may be considered particularly interesting is that performance expectation has a low effect on behavioral intention compared to other variables. Venkatesh et al. (2003) stated that performance expectation was the most important predictor in their 
organizational studies. However, according to Davis et al. (1989), the question of the extent to which organizational users are affected by their superiors in terms of their acceptance of technology raises questions. Therefore, since the performance expectancy refers to the total perceived benefit for the use of new technology, perhaps it will be healthier to identify the factors affecting this variable.

In this study, it was found that habit is the most important determinant of behavioral intention. At this point, the relationship between habit and trust, hedonic motivation, optimism, and innovativeness shows that a suitable model is formed as a theoretical foundation. While habit is a prominent concept in determining behavioral intention, it is necessary to examine in detail the relationship between predictors and variables. In this context, simpler models may be expected from future research. In the study, if all the paths are run on the model, the definition of the relationship networks and the behavioral intentions of these relationships as expected shows how complex the structure actually is. Therefore, developing these relationships further is recommended for providing guidance for future studies and to use them in different contexts or directly for the acceptance of certain products. 


\section{Eskişehir Osmangazi Üniversitesi İktisadi ve İdari Bilimler Fakültesi Dergisi}

\section{References}

Ajzen, I., \& Fishbein, M. (2005). The influence of attitudes on behavior. The handbook of attitudes, $173(221), 31$.

Ajzen, I. (2002). Perceived behavioral control, self-efficacy, locus of control, and the theory of planned behavior. Journal of applied social psychology, 32(4), 665-683.

Alalwan, A. A., Baabdullah, A. M., Rana, N. P., Tamilmani, K., \& Dwivedi, Y. K. (2018). Examining adoption of mobile internet in Saudi Arabia: Extending TAM with perceived enjoyment, innovativeness and trust. Technology in Society, 55, 100-110.

Alalwan, A. A., Dwivedi, Y. K., Rana, N. P., Lal, B., \& Williams, M. D. (2015). Consumer adoption of Internet banking in Jordan: Examining the role of hedonic motivation, habit, self-efficacy and trust. Journal of Financial Services Marketing, 20(2), 145-157.

Aldossari, M. Q., \& Sidorova, A. (2018). Consumer Acceptance of Internet of Things (loT): Smart Home Context. Journal of Computer Information Systems, 1-11.

AlHogail, A. (2018). Improving IoT Technology Adoption through Improving Consumer Trust. Technologies, 6(3), 64.

Ande, R., Adebisi, B., Hammoudeh, M., \& Saleem, J. (2020). Internet of Things: Evolution and technologies from a security perspective. Sustainable Cities and Society, 54, 101728.

Atzori, L., lera, A., \& Morabito, G. (2017). Understanding the Internet of Things: definition, potentials, and societal role of a fast evolving paradigm. Ad Hoc Networks, 56, 122-140.

Bagozzi, R. P., \& Yi, Y. (1988). On the evaluation of structural equation models. Journal of the academy of marketing science, 16(1), 74-94.

Baudier, P., Ammi, C., \& Deboeuf-Rouchon, M. (2018). Smart home: Highly-educated students' acceptance. Technological Forecasting and Social Change, 119355.

Beh, P. K., Ganesan, Y., Iranmanesh, M., \& Foroughi, B. (2019). Using smartwatches for fitness and health monitoring: the UTAUT2 combined with threat appraisal as moderators. Behaviour \& Information Technology, 1-18.

Bölen, M. C. (2020). Exploring the determinants of users' continuance intention in smartwatches. Technology in Society, 60, 101209.

Brauner, P., Van Heek, J., \& Ziefle, M. (2017). Age, gender, and technology attitude as factors for acceptance of smart interactive textiles in home environments. In Proceedings of the 3rd International Conference on Information and Communication Technologies for Ageing Well and e-Health, ICT4AgingWell.

Brown, S. A., \& Venkatesh, V. (2005). Model of adoption of technology in households: A baseline model test and extension incorporating household life cycle. MIS quarterly, 29(3).

Casola, V., De Benedictis, A., Riccio, A., Rivera, D., Mallouli, W., \& de Oca, E. M. (2019). A security monitoring system for internet of things. Internet of Things, 7, 100080.

Celic, L., \& Magjarevic, R. (2020). Seamless connectivity architecture and methods for loT and wearable devices. Automatika, 61(1), 21-34.

Chin, W. W., Peterson, R. A., \& Brown, S. P. (2008). Structural Equation Modeling in Marketing: Some Practical Reminders. Journal of Marketing Theory and Practice, 16(4), 287-298.

Chin, W. W. (1998). The partial least squares approach to structural equation modeling. Modern methods for business research, 295(2), 295-336.

Churchill Jr, G. A. (1979). A paradigm for developing better measures of marketing constructs. Journal of marketing research, 16(1), 64-73.

Chipeva, P., Cruz-Jesus, F., Oliveira, T., \& Irani, Z. (2018). Digital divide at individual level: Evidence for Eastern and Western European countries. Government Information Quarterly, 35(3), 460-479. 
Chong, A. Y. L., \& Chan, F. T. (2012). Structural equation modeling for multi-stage analysis on Radio Frequency Identification (RFID) diffusion in the health care industry. Expert Systems with Applications, 39(10), 8645-8654.

Cohen, J. (1988). Statistical power analysis for the behaviors science. (2nd). New Jersey: Laurence Erlbaum Associates, Publishers, Hillsdale.

Davis, F. D., Bagozzi, R. P., \& Warshaw, P. R. (1989). User acceptance of computer technology: a comparison of two theoretical models. Management science, 35(8), 982-1003.

Dhaggara, D., Goswami, M., \& Kumar, G. (2020). Impact of Trust and Privacy Concerns on Technology Acceptance in Healthcare: An Indian Perspective. International Journal of Medical Informatics, 104164.

Diamantopoulos, A., \& Siguaw, J. A. (2006). Formative versus reflective indicators in organizational measure development: A comparison and empirical illustration. British Journal of Management, 17(4), 263-282.

Dutot, V., Bhatiasevi, V., \& Bellallahom, N. (2019). Applying the technology acceptance model in a three-countries study of smartwatch adoption. The Journal of High Technology Management Research, 30(1), 1-14.

El-Masri, M., \& Tarhini, A. (2017). Factors affecting the adoption of e-learning systems in Qatar and USA: Extending the Unified Theory of Acceptance and Use of Technology 2 (UTAUT2). Educational Technology Research and Development, 65(3), 743-763.

Ferreira, J. B., da Rocha, A., \& da Silva, J. F. (2014). Impacts of technology readiness on emotions and cognition in Brazil. Journal of Business Research, 67(5), 865-873.

Fornell, C., \& Larcker, D. F. (1981). Evaluating structural equation models with unobservable variables and measurement error. Journal of marketing research, 18(1), 39-50.

Gaitán, J., Peral Peral, B., \& Ramón Jerónimo, M. (2015). Elderly and internet banking: An application of UTAUT2. Journal of Internet Banking and Commerce, 20 (1), 1-23.

Gao, Y., Li, H., \& Luo, Y. (2015). An empirical study of wearable technology acceptance in healthcare. Industrial Management \& Data Systems, 115(9), 1704-1723.

Gao, L., \& Bai, X. (2014). A unified perspective on the factors influencing consumer acceptance of internet of things technology. Asia Pacific Journal of Marketing and Logistics, 26(2), 211-231.

Gefen, D., Karahanna, E., \& Straub, D. W. (2003). Trust and TAM in online shopping: an integrated model. MIS quarterly, 27(1), 51-90.

Hair Jr, J. F., Hult, G. T. M., Ringle, C., \& Sarstedt, M. (2016). A primer on partial least squares structural equation modeling (PLS-SEM). Sage publications.

Henseler, J., Hubona, G., \& Ray, P. A. (2016). Using PLS path modeling in new technology research: updated guidelines. Industrial management \& data systems.

Henseler, J., \& Sarstedt, M. (2013). Goodness-of-fit indices for partial least squares path modeling. Computational Statistics, 28(2), 565-580.

Henseler, J., Ringle, C. M., \& Sinkovics, R. R. (2009). The use of partial least squares path modeling in international marketing. In New challenges to international marketing (pp. 277-319). Emerald Group Publishing Limited.

Hsu, C. L., \& Lin, J. C. C. (2016). An empirical examination of consumer adoption of Internet of Things services: Network externalities and concern for information privacy perspectives. Computers in Human Behavior, 62, 516-527.

Johnson, V. L., Kiser, A., Washington, R., \& Torres, R. (2018). Limitations to the rapid adoption of Mpayment services: Understanding the impact of privacy risk on M-Payment services. Computers in Human Behavior, 79, 111-122. 
Kağnicioğlu, C. H., \& Çolak, H. (2019). Tüketicinin Nesnelerin Interneti Teknolojilerini Benimsemesi ve Bir Uygulama. Anadolu Üniversitesi Sosyal Bilimler Dergisi, 19(4), 241-268.

Khattak, H. A., Shah, M. A., Khan, S., Ali, I., \& Imran, M. (2019). Perception layer security in Internet of Things. Future Generation Computer Systems, 100, 144-164.

Kim, S. S., Malhotra, N. K., \& Narasimhan, S. (2005). Research note-two competing perspectives on automatic use: A theoretical and empirical comparison. Information systems research, 16(4), 418-432.

Kim, S. S., \& Malhotra, N. K. (2005). A longitudinal model of continued IS use: An integrative view of four mechanisms underlying postadoption phenomena. Management Science, 51(5), 741-755.

Kim, J., \& Park, E. (2019). Beyond coolness: Predicting the technology adoption of interactive wearable devices. Journal of Retailing and Consumer Services, 49, 114-119.

Kuo, K. M., Liu, C. F., \& Ma, C. C. (2013). An investigation of the effect of nurses' technology readiness on the acceptance of mobile electronic medical record systems. BMC medical informatics and decision making, 13(1), 88.

Lee, I. (2019). The Internet of Things for enterprises: An ecosystem, architecture, and loT service business model. Internet of Things, 7, 100078.

Lee, W., \& Shin, S. (2019). An empirical study of consumer adoption of Internet of Things services. International Journal of Engineering and Technology Innovation, 9(1), 1.

Limayem, M., Hirt, S. G., \& Cheung, C. M. (2007). How habit limits the predictive power of intention: The case of information systems continuance. MIS Quarterly, 31(4).

Luhmann, N. (2000). Familiarity, confidence, trust: Problems and alternatives. Trust: Making and breaking cooperative relations, 6(1), 94-107.

Manzano, J., Lassala-Navarré, C., Ruiz-Mafé, C., \& Sanz-Blas, S. (2009). The role of consumer innovativeness and perceived risk in online banking usage. International Journal of Bank Marketing, 27(1), 53-75.

Martino, B., Rak, M., Ficco, M., Esposito, A., Maisto, S. A., \& Nacchia, S. (2018). Internet of things reference architectures, security and interoperability: A survey. Internet of Things, 1, 99-112.

Midgley, D. F., \& Dowling, G. R. (1978). Innovativeness: The concept and its measurement. Journal of consumer research, 4(4), 229-242.

Morrison, D. E., \& Firmstone, J. (2000). The social function of trust and implications for e-commerce. International Journal of Advertising, 19(5), 599-623.

Nascimento, B., Oliveira, T., \& Tam, C. (2018). Wearable technology: What explains continuance intention in smartwatches?. Journal of Retailing and Consumer Services, 43, 157-169.

Oliveira, T., Thomas, M., Baptista, G., \& Campos, F. (2016). Mobile payment: Understanding the determinants of customer adoption and intention to recommend the technology. Computers in Human Behavior, 61, 404-414.

Parasuraman, A., \& Colby, C. L. (2015). An updated and streamlined technology readiness index: TRI 2.0. Journal of service research, 18(1), 59-74.

Park, E. (2020). User acceptance of smart wearable devices: An expectation-confirmation model approach. Telematics and Informatics, 47, 101318.

Peng, D. X., \& Lai, F. (2012). Using partial least squares in operations management research: A practical guideline and summary of past research. Journal of Operations Management, 30(6), 467-480.

Rahman, S. A., Taghizadeh, S. K., Ramayah, T., \& Alam, M. M. D. (2017). Technology acceptance among micro-entrepreneurs in marginalized social strata: The case of social innovation in Bangladesh. Technological Forecasting and Social Change, 118, 236-245. 
Ramantoko, G., Putra, G., Ariyanti, M., \& Sianturi, N. V. (2016, March). Early Adoption Characteristic of Consumers' Behavioral Intention to Use Home Digital Services in Indonesia. In 3rd International Seminar and Conference on Learning Organization. Atlantis Press.

Roy, S., \& Moorthi, Y. L. R. (2017). Technology readiness, perceived ubiquity and M-commerce adoption: The moderating role of privacy. Journal of Research in Interactive Marketing, 11(3), 268-295.

Sanguinetti, A., Karlin, B., \& Ford, R. (2018). Understanding the path to smart home adoption: Segmenting and describing consumers across the innovation-decision process. Energy research \& social science, 46, 274-283.

Schill, M., Godefroit-Winkel, D., Diallo, M. F., \& Barbarossa, C. (2019). Consumers' intentions to purchase smart home objects: Do environmental issues matter?. Ecological Economics, 161, 176-185.

Seol, S., Ko, D., \& Yeo, I. (2017). UX Analysis based on TR and UTAUT of Sports Smart Wearable Devices. KSII Transactions on Internet \& Information Systems, 11(8).

Sevim, N., Yüncü, D., \& HALL, E. E. (2017). Online seyahat ürünlerinde genişletilmiş teknoloji kabul modelinin analizi. Internet Uygulamaları ve Yönetimi Dergisi, 8(2), 45-61.

Shin, D. H. (2010). The effects of trust, security and privacy in social networking: A security-based approach to understand the pattern of adoption. Interacting with computers, 22(5), 428-438.

Shin, S., \& Lee, W. J. (2014). The effects of technology readiness and technology acceptance on NFC mobile payment services in Korea. Journal of Applied Business Research, 30(6), 1615.

Silva, B. N., Khan, M., \& Han, K. (2018). Internet of things: A comprehensive review of enabling technologies, architecture, and challenges. IETE Technical review, 35(2), 205-220.

Sułkowski, Ł., \& Kaczorowska-Spychalska, D. (2017, July). Consumer Perception of Internet of Things. In International Conference on Applied Human Factors and Ergonomics (pp. 247-258). Springer, Cham.

Tenenhaus, M., Vinzi, V. E., Chatelin, Y. M., \& Lauro, C. (2005). PLS path modeling. Computational statistics \& data analysis, 48(1), 159-205.

Tewari, A., \& Gupta, B. B. (2020). Security, privacy and trust of different layers in Internet-of-Things (IoTs) framework. Future generation computer systems, 108, 909-920.

Thompson, R. L., Higgins, C. A., \& Howell, J. M. (1994). Influence of experience on personal computer utilization: testing a conceptual model. Journal of management information systems, 11(1), 167-187.

Tsai, J. Y., Egelman, S., Cranor, L., \& Acquisti, A. (2011). The effect of online privacy information on purchasing behavior: An experimental study. Information Systems Research, 22(2), 254-268.

Venkatesh, V., Thong, J. Y., \& Xu, X. (2012). Consumer acceptance and use of information technology: extending the unified theory of acceptance and use of technology. MIS Quarterly, 36(1), 157-178.

Venkatesh, V., Morris, M. G., Davis, G. B., \& Davis, F. D. (2003). User acceptance of information technology: Toward a unified view. MIS Quarterly, 425-478.

Venkatesh, V., \& Davis, F. D. (2000). A theoretical extension of the technology acceptance model: Four longitudinal field studies. Management Science, 46(2), 186-204.

Wei, T., Marthandan, G., Yee-Loong Chong, A., Ooi, K. B., \& Arumugam, S. (2009). What drives Malaysian m-commerce adoption? An empirical analysis. Industrial Management \& Data Systems, 109(3), 370-388.

Wetzels, M., Odekerken-Schröder, G., \& Van Oppen, C. (2009). Using PLS path modeling for assessing hierarchical construct models: Guidelines and empirical illustration. MIS Quarterly, 177-195.

Wu, L. H., Wu, L. C., \& Chang, S. C. (2016). Exploring consumers' intention to accept smartwatch. Computers in Human Behavior, 64, 383-392.

Yan, Z., Zhang, P., \& Vasilakos, A. V. (2014). A survey on trust management for Internet of Things. Journal of network and computer applications, 42, 120-134. 
Zhang, M., Luo, M., Nie, R., \& Zhang, Y. (2017). Technical attributes, health attribute, consumer attributes and their roles in adoption intention of healthcare wearable technology. International journal of medical informatics, 108, 97-109.

Zhao, X., Lynch Jr, J. G., \& Chen, Q. (2010). Reconsidering Baron and Kenny: Myths and truths about mediation analysis. Journal of consumer research, 37(2), 197-206. https://doi.org/10.1086/651257

https://www.statista.com/statistics/471264/iot- number- of- connected- devicesworldwide. 